\title{
SİGORTA SEKTÖRÜNÜN YARATTIĞI KAMUSAL DIŞSALLIKLAR
}

\author{
PUBLIC EXTERNALITIES CAUSED BY INSURANCE SECTOR
}

Hakan ÖZCAN ${ }^{(1)}$, Nuriye Zeynep ÖKTEN(2), İbrahim UZPEDER ${ }^{(3)}$

Öz: Sigorta sektörünün ekonomideki çarpan etkisi, yarattı̆̆ı dişsallıklar sayesinde yüksektir. Gelişmekte olan Türkiye ekonomisinin yatırımlar için ihtiyaç duyduğu tasarruf, finansman imkanları, güven ortamı, risklerin azaltılması gibi ana etkenlerde sigorta sektörünün katkısı büyük olacaktır. Küresel sigortacılık payı içinde Türkiye'nin sektör payı kapasitesine oranla düşük kalmaktadır. Bu makalenin amacı sigorta sektörünün ekonomi üzerinde yarattığı dışsallıkları irdeleyerek Türkiye'deki sigorta sektörünün gelişimi konusunda devletin düzenleyici rolü üzerine dikkat çekmektir.

Anahtar Kelimeler: Sigorta, Kamu, Pozitif Dışsallık, Negatif Dışsallık

\begin{abstract}
Since insurance sector causes externalities, its multiplier effect on national economies is significant. Its contribution to Turkey's developing economy is remarkable regarding main factors such as savings required for investment, financing feasibilities, trust climate, reduction of risks. Turkey's insurance penetration remains low in comparison to world insurance penetration share with respect to national income per capita. The goal of this article is to point to public sector's regulatory role in insurance sector development by examining externalities by the means of insurance.
\end{abstract}

Keywords: Insurance, Public Sector, Positive Externalities, Negative Externalities

JEL: G22, HO, D62

\section{Giriş}

Ekonomik aktörler olan birey ve kurumlar kendi fayda ya da karlarını en çoklaştırmak isteği içinde uyguladıkları ekonomik aksiyonlar esnasında hiçbir organik bağı olmayan diğer ekonomik birimlere dolaylı ya da dolaysız olarak pozitif veya negatif bir etkide bulunarak dışsallık yaratırlar. Ekonomik aktiviteler içinde önemli bir yer tutan sigorta sektörü de toplumsal dişsallıklar yaratmaktadır

Sigorta, riskin belli bir prim karşılığında aynı riskle karşı karşıya bulunan kişiler arasında dağıtılarak belli şartlar altında teminat altına alınmasıdır. Aynı zamanda bireylerin zararlarının diğer katılımcıların desteği ile sonuçlandığı bir risk transferidir. Diğer bir tanıma göre ise, bir tarafın diğerine prim ödemesi ve diğer tarafın bu prim karşılığında güvence verdiği bir kaybın ortaya çıkması halinde; zarar ödemeyi taahhüt ettiği iki taraflı bir sözleşme ilişkisidir. Türk Ticaret Kanunu'na göre sigorta sözleşmesi şu şekilde tanımlanmaktadır (Resmi Gazete, 2011b): "Sigortacının prim karşılığı, bireyin para ile ölçülebilen bir değerini zarara neden olan tehlikenin oluşması hâlinde bunu ödemeyi veya bir ya da daha fazla bireyin yaşam süreleri sebebiyle veya hayatlarında oluşan bazı vakalar sebebi ile tazminat ödemeyi taahhüt ettiği bir sözleşmedir." Tüm bu tanımlarda bulunan 'belli bir prim karşılı̆̆ında'

(1) İstanbul Okan Üniversitesi, İşletme ve Yönetim Bilimleri Fakültesi, İşletme Bölümü; hakan.ozcan@okan.edu.tr, ORCID: 0000-0002-4000-9830

(2) Nişantaşı Üniversitesi, İktisadi, İdari ve Sosyal Bilimler Fakültesi, Uluslararası Ticaret Bölümü; zeynep.okten@nisantasi.edu.tr, ORCID: 0000-0002-3848-3488

(3) Beykent Üniversitesi, İşletme ve Yönetim Bilimler Fakültesi, İşletme Bölümü; ibrahimuzpeder@beykent.edu.tr, ORCID: 0000-0003-3027-6289

Geliş/Received: 04-02-2021; Kabul/Accepted: 01-07-2021 
ifadesinden de anlaşılacağı üzere prim, sigortacının devraldığı riske karşılık, sigortalının ödediği güvence bedelidir.

Sigorta bireysel (kurumsal) bir eylem olarak tanımlanarak risklere karşı ekonomik bireyi belirli bir prim ödemesi karşılığında güven altına alan bir sistem olarak düşünülse de aslında kamusal mal olma özelliğini de içinde barındırmakta ve üçüncü kişilere da dışsallık yaratmaktadır. Bireyin yaşamı ve sahip olduğu malları hayatının her döneminde çeşitli tehlikelere maruz kalmaktadır (Acınan, 2005:16). Sigortacılık uygulamaları benzer riskler ile karşılaşma ihtimali olan bireylerin bir yardımlaşma sistemi olarak başlamış; zaman içinde ticarete, vergi kaynaklarına ve girişimciler için kredi imkanlarına destek olmuştur. Sigortacılık uygulamalarının ekonomik gelişme ve büyümeye olumlu etkileri yanında fon yaratma işlevi ile de mali sistemde etkin bir rolü olmuştur. Bu etkinin farkında olan toplumlar gelişme ve büyümelerinde sigorta sektöründen yararlanmaya çalışmışlardır (Arseven, 1987: 418).

Dünya sigorta istatistikleri incelendiğinde; ekonomik anlamda gelişmiş ülkelerin sigorta sektörünün diğer ülkelere oranla gelişmiş olduğu görülmektedir (Swiss Re, 2020). Sigorta bilincinin ve kültürünün gelişmesi kişi başına düşen gelirin artışı ve aynı zamanda sosyal bilincin yükselmesi ve içsel ile dışsal güvenlik yaratılması ile alakalıdır.

İçsel güvenlik; manevi denge, düzen, oryantasyon ve güvence duygusu olarak izah edilebilir. Dışsal güvenlik; bireylerin mali yönden kendisini tatminkâr hissetmesi ile çevresel ilişkilerinde duymak istedikleri güven gibi ihtiyaçlar olarak tanımlanabilir. Başka bireyler için güvence sisteminde; üçüncü kişilere ulaşım, dürüstlük, oryantasyon ile düzen güvenliği bulunmaktadır. Farklı bireylere yönelik ruhsal ile bedensel uyum ve güvence beklentisi de bu amaçlardan kabul edilir (Haller, 1974: 14).

Dışsallık kavramı ekonomik literatür içinde kamusal ya da yarı kamusal mallara ilişkin çokça araştırılmış olsa da sigorta hizmetinin yaydığı dışsallık etkisine ilişkin kapsamlı çalışmalar eksik kalmıştır. Ekonomi literatüründe üzerinde fazla çalışılmayan bu alanda gelecek dönemlerde daha öncü bir makale olmak ve gelecekte bu konuda yazılacak makalelere öncü olmak amacımızdır.

\section{Sigorta ve Dışsallıklar İlişkisi}

Sigorta sistemi, birimlerin riskleri önden satın alması sayesinde toplumun geneline yayılan dışsallıklar yaratır. Sigorta, ölüm, hastalık, sakatlık, doğal afetler, yangın, hırsızlık, risklerin meydana gelmesinden dolayı oluşacak zararların önüne geçerek toplumda huzur ve güven sağladığ 1 gibi; gelecekte meydana gelebilecek riskler ile korkmadan yaşama imkânı sunar. Böylelikle kurumlar ve fertler sosyal ve ekonomik hayatta kendilerini güvende hisseder. Sigortacılık aynı riski taşıyan işletme ve bireylerin bir fon oluşturması ve kendi başlarına karşılayamayacakları finansal kayıpların bu fondan karşılanması sistemidir (Willett, 1901: 105) Dayanışma esasına dayalı olan sistemi sigorta şirketleri kurar ve yürütürler (Houtepen ve Meulen, 2000: 329). Sigorta yaptıran birimler olası risklerin gerçekleşmesi durumunda meydana gelecek zararı önden fiyatlayarak primlerini öder böylece gelecekte serbest piyasada oluşacak maliyetteki belirsizliği ortadan kaldırmış olurlar satın almış olurlar. Hasar prim dengesi sigortaya ilişkin talebi belirleyen önemli unsurlardandır ve bu sorumluluk sigorta şirketine aittir (Seyfullahoğulları ve Başoğlu, 2018: 15). 


\section{Sigortacılığın Yarattığı Pozitif Dışsallıklar}

\subsection{Ekonomik Büyüme Finansal Sistem ilişkisi}

Neo-Klasik büyüme teorisine göre gelişmede teknolojinin rolü büyüktür ve teknolojik gelişmenin olmadığı ekonomiler ancak durağan durumlarda büyüyebilir. Bu durum hükümetlerin ekonomik büyümede teşvik sistemini kullanmasını kısmen engeller (Hussel, 2005: 257). Neo-Klasik büyüme teorisinin eksik kaldığı alanı içsel büyüme teorisi dışsallıkları teoriye dahil ederek teknolojik gelişmenin olmadığı ekonomilerde büyümenin temellerini açıklayarak literatüre katkıda bulunmuştur. İçsel büyüme teorisinde; bir sektörde yaşanan büyüme ile yatırımların diğer sektörlerde de pozitif dışsallık etkisinin olduğundan bahsedilmiştir. Bu sebeple içsel büyüme teorisinde, ekonomik büyümenin durağan durumlar da pozitif dışsallıklar etkisi ile ekonominin geri kalanında büyümenin artacağını öngörülmüştür. Banka ve sigorta gibi finans sektörlerinin pozitif dışsallıkları yayılmasında büyük bir etkisi vardır.

Finansal gelişmelerin ekonomik büyümede öncü rolünü ekonomik analizlerde görmek mümkündür. Başarılı finans kurumları tasarrufların artışı, etkin sermaye dağılımı ve oluşumu ile ekonomik büyümeye destek olmaktadır. Sermaye için tasarruflara dolayısı ile tüketimden artan kaynağa gereksinim bulunmaktadır. Mal ve hizmet üretmek için kullanılan sermayeye tasarruf sahiplerinden yatırımcılara doğru yönlendirilmesi gerekmektedir (Alkin, 1992: 136). Ekonomik işlevin tam olarak işleyebilmesi için sigorta fonlarının sermaye piyasalarında değerlendirilmesi gerekmektedir. Finans piyasaları ve aracıları; kaynakların yatırımcılara doğru yönlendirilmesinde çok önemli bir kontrol görevini üstlenmişlerdir. (Ünal, 1994: 30).

Yapılan araştırmalara göre; finansal gelişim ile iktisadi büyüme arasında pozitif bir ilişki bulunmaktadır. İktisadi gelişmeye paralel yaygınlaşan ve büyüyen sigortanın, toplumların gelişim seviyesinin tespitinde önemli bir indikatör olduğu kabul edilmektedir. Gelişmiş ülkelerde sigorta priminin milli gelir içerisinde payı en üst sıralarda olup büyük bir fon yaratma kapasitesi bulunmaktadır. Bu ülkelerdeki sigorta şirketlerinin rekabete bağlı olarak teknik karları azalmasına rağmen, artan mali karlarının desteği ile diğer finansal kurumlar gibi yatırım faaliyetleri yapmaktadır. Ekonomik büyüme ve sigorta sektörü arasındaki nedensellik ilişkisinde; ekonomik sistem, mevzuat ve kültürün büyük etkisi bulunmakta olup, bu durum ülkelere göre farkl1lık gösterebilmektedir (Ward ve Zurbruegg, 2000: 489).

İktisat biliminde uzun süreden beri hâkim olan görüşe göre, finansal sistemlerde yapılacak inovasyonlar başta verimlilik olmak üzere ülke ekonomisine faydalar sağlamaktadır (Hartmann vd., 2007: 5). Teknolojik gelişmenin sadece reel sektörde oluşmayacağı finansal sektörde de ortaya çıkabileceği görüşü sigortacılığın dişsallık etkisinin önemini de arttırmaktadır. Sigortalıların kimi zaman sistem kaynaklı sorunlar yaşamasına rağmen; sigortanın kullanılmasının ekonomik performans, kaynakların dengeli dağılımını ve gelişme üzerinde büyük bir etkisi bulunmaktadır. Sigortacılık uygulamaları yaygınlaştıkça finansal işlevlerin etkinliği de artar, büyüme ve ekonomik gelişmedeki olumlu etkisi yanında itici bir güç şeklini almaktadır (Riegel ve Miller, 1966: 6).

\subsection{Kalkınma ve Refah etkisi}

Ekonomik büyüme rakamsal veriler olup topluma yayılma etkisi zaman almaktadır. Toplumsal refah artışı ancak insan haklarının, demokrasinin, adaletin, gelir dağılımının ve yaşam kalitesinin iyileştirilmesi ile sağlanabilir. İnsani kalkınmanın sağlanması için ekonomik büyüme ön koşuldur ancak yeterli değildir. Sigorta sektörü 
ekonomik gelişimi beslerken topluma yayılan refah etkisi de sigortacıllk sektörünü büyütecek böylece karşılıklı bir bağımlılık oluşacaktır. Gelişen ekonomilerde insanların refahı arttıkça sigortanın önemi de anlaşılacak ve sigorta ekstra bir harcama olarak değil geleceğe güven sağlayan, konfor alanı yaratan insani bir ihtiyaç olarak kabul edilecektir. Sigorta, maddi değerlerin teminat verilmesi ve zenginliklerin güvence görevini de üstlenen bir disiplin olmasından dolayı, sigorta ve insani kalkınma arasında da bir ilişkinin olması doğaldır (Zortuk \& Ebeoğlugil, 2016: 1).

Bir toplumun sosyal refah düzeyini belirleyen en önemli ölçüt kişi başı gelir düzeyinin zaman içerisinde artmasıdır. Gelirde artış sağlamak için yatırımlarda ve üretim değerinde artış yaşanmalıdır. Yatııımlar için gerekli olan sermaye birikimi tasarruflarla sağlanabilir. Sigorta bireyleri ve kurumları sosyal refahı iyileştirecek davranışlara yöneltir (Kunreuther vd., 2013: 1). Kişiler ve firmalar kendilerini risklere karşı korurken toplumsal tasarrufları arttırarak pozitif ekonomik dışsallık yaratırlar.

\section{3. İstihdam Etkisi}

Sigortacılığın istihdama etkisi değerlendirilirken sadece sektör içi çalışanları dikkate almak doğru bir yaklaşım değildir. Türk sigorta şirketlerinde çalışan sayısının 2019 yılı itibarı sadece yaklaşık 14.000 kişi (TSB, 2020a) olmasına rağmen, hasarların karşılanması ile işletmelerin faaliyetlerinin devamını sağlayarak, çalışanların istihdam kaybının önüne geçmektedir (Sukhdev, 2012: 136). Özellikle gelişmekte olan ülkelerin istihdam yaratma konusunda yaşadığı zorlukları düşünürsek sigorta sektörünün yarattığı çalışma olanağı insanların ücret ve kar gelirleri elde etmesiyle gelirlerini arttırma konusunda önemli bir görevi üstlendiği de görülmektedir.

\subsection{Belirsizlik ve Risk Etkisi}

Küresel ve yerel ekonomilerin yaşadığı ekonomik krizler ya da jeopolitik riskler ile ortaya çıkan belirsizlikler ekonomide yatırım yapma kararını zorlaştıran ve yatırım oranlarını düşüren sorundur. Belirsizlik, risk olgusu gibi ölçülmesi olanaklı bir durum değildir bu yüzden, belirsizliğin fazla olduğu dönemler girişimcinin karar vermesi için belirsizliği en aza indirmesi gerekir (Balta, 1997: 56). Ancak sigortanın sağladığ güven etkisi ile girişimciler ve sermayedarlar daha kolay yeni yatırımlar yaparak ülkenin gelişmesine katkı sağlamaktadır. Gelişmekte olan ülkelerde sermayenin zor bulunan bir kaynak olması ve oluşacak zararlara ilişkin tedbir amaçlı bir kenarda tutulması yerine az bir prim ödeyerek risklerini sigorta sisteminde güvence altına alınması ihtiyaç amaçlı tutulacak ve âtıl kalacak sermayeyi üretime yönlendirir (Uralcan, 2004: 55).

\subsection{Kredi olanakları ve Faiz etkisi}

Ekonomi içinde yapılacak yatııımların kaynağı tasarruflardır ve hane halkı tarafından elde edilen gelirin şekli ile kullanımının; ulusal tasarruf ve gelirler için çok önemlidir (Taban \& Şengür, 2016: 49). Bilindiği üzere düşük gelir gruplarında marjinal tüketim alışkanlığı yüksektir. Bireyler birçok sebep ile gelirlerinden kendilerince tasarruf yapamadığı kısımları bir sigorta ürününe yönlendirebilir. Tüm gelir grupları için tasarruf olanağının yaratılması sigorta sektörünün önemli dışsallıklarındandır.

Faiz finansal piyasa içinde borçlanma talebi ile borç verme arzı arasındaki ilişkiye bağlı olarak belirlenir. Reel faiz borçlanma maliyeti olarak ortaya çıkar kişiler de tasarruf edip finansal piyasaya borç verme arzında bulunurken bugünkü tüketimini geleceğe erteleme karşlığında faiz geliri elde ederler. Borçlanma talebi sabitken borç verme arzı yani tasarruflar artarsa faiz oranında sanki para arzı artmışçasına düşüş 
yaşanır. Oluşabilecek zararlara karşı maddi korunma imkânı yaratan sigorta sistemi aynı zamanda topladığı fonlarla tasarrufları arttırırken yatırım kararında önemli bir etken olan faizlerin düşüşüne pozitif dışsallık yaratır ve yatırımların artmasına sebep olur.

Finans piyasalarının gelişmiş ve derinleşmiş olması kolay ve ucuz finansman olanaklarına kavuşmak isteyen yatırımcı için önemlidir. Gelişen finansal sistem ve kredi havuzu yatırımları arttırırken ekonomik büyümeyi de destekler. Sigorta sektörü bir yandan fonlarıyla finansman sistemini desteklerken diğer yandan sağladığ güvence desteği ile yatırımcının finansmana ulaşımını kolaylaştırır. Yeni yatırımı için kredi talebinde bulunan tarafın rahatça finansman olanağına kavuşabilmesi için finansal kurumları karşısında elinin güçlü olması lazımdır. Finansman kurumları ise alacağını garanti altına almak isterken krediyi vereceği kişi veya kurumdan ipotek gibi maddi garantiler yani teminatlar ister (Yuca, 2012: 1). Sermaye yatırımı için kredi kullananların, sigorta poliçesi olmadan teminatlarının kabul edilmesi mümkün değildir. Sonuçta uygun bir sigorta poliçesi olan girişimci kredi temininde zorlanmayacaktır (Çiftçi, 2004: 124).

\subsection{Uluslararası Ticarete Etkisi}

Taşımacılık sürecinde yük, araç ve sorumluluk risklerine karşı güvenceler alınmadan nakliyatın yapılması mümkün görünmemektedir. $\mathrm{Bu}$ sebepten ötürü ticaretin küreselleşmesinde sigortacılığın çok önemli bir payı vardır. Yurt içinde üretilen malların ihracatında çeşitli riskler için ihracat kredi sigortası önemli bir araçtır. İhracat kredi sigortasının kredili satış riskleri azaltmada ve uluslararası rekabette taşıdığı değer çok büyüktür (Aksoy, 2017: 66). Bu sigorta yardımı ile ihracatçıların riskleri azalmakta ve uluslararası arenada etkin bir rol oynama ve daha rahat ticaret yapabilme imkânı sağlanmaktadır.

Ayrıca sigortacılığın küreselleşme eğilimleri de ödemeler dengesini etkilemektedir. Reasürans ve sigorta işlemlerindeki prim, ülke ekonomisine döviz sağlayarak diş ödemeler dengesi için destek olabilmektedir (Yücememiş vd., 2011: 59).

\subsection{Hazine ve Vergi Etkisi}

Ülke ekonomileri açısından sigortanın diğer bir önemi de tasarruflara bağlı olarak vergi sistemine olan katkısıdır. Sigortacılık işletmeleri sene sonunda bilançolarına paralel kendi paylarına düşen vergiyi öderler. Sigortacılar ayrıca gayrimenkul, tahvil ve hisse senedi gibi yatırım araçlarından da bina/gelir vergisi öderler. Poliçelerdeki prim bazlı gider, yangın söndürme vergisi; vefat teminatlı sigortalarda veraset ve intikal vergileri tahakkuk ettirilmektedir. Sigortacılığın yükselen performansının doğrudan ya da dolaylı olarak daha yüksek vergi geliri ile kamu finansmanında olumlu etkileri olmaktadır (Uyanık, 2005: 2).

Bireysel emeklilik, hayat ve özel sağlık sigorta sistemleri; sosyal güvenlik kurumları için ilave bir sigorta önemini taşımaktadır. Mesela özel emeklilik sigortaları sosyal güvenlik sistemlerine ilave emeklilik firsatı ile destek sağlamaktadır. Böylelikle sosyal güvenlik sistemlerindeki ilave yükler ve dolayısı ile devlet bütçesinden olası açıklara aktarılan kaynak miktarı azalmaktadır (Özcan, 2020: 171).

\subsection{Dalga Etkisi}

Sigortacı risk seçiminde sigortalıyı bazı olası hasarlar için; önleme ve zararı azaltma tedbirleri almaya zorlayabilir. Örneğin sigortacı yangın önleme için sprinkler tesisatı, sel için yerden yüksek raf sistemleri veya hırsızlık için alam sistemleri yapılması 
isteyebilir (Hofmann, 2009: 5). Bu tedbirlerin bir kısmı "kendini koruma" zararı azaltma, diğer ise "kendini güvenceye alma" hasar ihtimalinin azalmasına yöneliktir. Risk almaktan çekinen kişi daha fazla sigorta yaptırmaya eğilimlidir (Ehrlich ve Becker, 1972: 623). Sigorta ve kendini güvenceye alma birbirini ikame veya tamamlayıc1 olabilir. Tamamlayıc1 olgusunda sigorta kapsamı kendini korumay teşvik eder ve böylece kayıp olasılığını azaltır. Bu olgu "ahlaki zorunluluk" olarak adlandırılmıştır (Wu ve Colwell, 1988: 101).

Ülkeler tarım sigorta prim sübvansiyonlarını talep, arz ve mali dengeler üzerindeki etkilerine göre belirlerler. Çiftçinin tarım alanlarındaki ürünü aynı zamanda kamu malı özelliği gösterdiği için devlet tarafından desteklenmektedir. Olası bir doğal afet sonucu çiftçilerin karşılamayacağı risklere karşıllk sigorta şirketlerince teklif edilebilecek poliçe tutarları maliyet olarak yüksek kalacağından, kamunun sigorta primlerini belirli oranlarda karşılaması pozitif bir dışsallıktır. Devlet destekli tarım ve hayvancılık sigortalarının öncelikli amacı kar etmek olmayıp, olası hasarların sigorta havuzundan karşılanması amaçlanmaktadır (Mahul vd., 2010: 56).

\section{Sigortacılığın Yarattığı Negatif Dışsallıklar}

Sigortac1, sigortalıların "kendini güvenceye alma" ve "kendini koruma" tutum ve davranışlarını gözlemleme imkânı yoktur. Sigortalının, "kendini güvenceye alma" ve "kendini koruma" tanımlanan tedbirli tutum ve davranışlara özen göstermemesi "ahlaki tehlike"ye yol açar. Ahlaki tehlike, genel anlamda, taraflardan birinin sözleşmede kendi lehine davranış değişikliğine gitmesi olarak tanımlanır (Fidan, 2011: 41).

Bir kişi hayatındaki risklere karşı tedbirli tutum ve davranışlar sergiler. Bu dışsallık durumunda, sigorta güvencesine sahip kişinin tedbirli davranışları azaltır. Örneğin kasko poliçesi olan bir sigortalı araç kullanırken teminatına güvenerek daha dikkatsiz davranabilir. Dolayısıyla sigortacılıkta ahlaki tehlike hem zarar ihtimali hem de hasarın artması anlamına gelmektedir.

Sigortalının poliçesine güvenerek daha dikkatsiz otomobil kullanması; sadece kendisi için değil diğer araç ve yayalar için risk oluşturmaktadır (Hofmann, 2009: 38). Bireyin kendi aracını veya kendisine kullanım için tahsis edilen kurum araçlarını aynı hassasiyet ile kullanmadığı bilinmektedir. Aynı durum uzun süreli kiralık araçlar için de geçerlidir. Bunun sonucunda sigorta prim hesaplamalarında bu tip araçların pimleri hususi araçlara göre daha yüksek çıkmaktadır (Vickrey, 1968: 468). Bu da toplum için negatif dışsallıktır.

Sigortacı başlangıçta risk havuzunda tüm katılımcıları eşit görmek durumundadır. Sigorta priminin hesaplaması bir sonraki yılın ödenecek hasar tahminine göre yapılmaktadır. Ancak sigortacının bu tahminde yanılması gelecek seneki sigorta primlerine olumsuz olarak yansıyacak ve risk havuzundaki tüm katılımcılar ortalama prim artışından otomatik olarak etkilenecektir (Hofmann, 2009: 2). Böylece havuzdaki riski az olan katılımcı ortalama risk priminin yükselmesi sebebi ile poliçe satın almaktan vazgeçebilecektir. Sigorta satın almada yaşanan çekimserlikler diğer poliçe yaptıracakları da olumsuz etkileyebilmektedir. Toplumun genelinin sigorta yaptırmaya karşı mesafeli tutumları, kimsenin sigorta yaptırmama tehlikesine neden olabilecektir. Tüm toplumun sigorta yaptırması durumunda bireysel poliçe maliyetleri azalacaktır (Heal ve Kunreuther, 2005: 36).

Sigortalının bulunduğu ortam için satın aldığı risk yakın çevresi için de faydalı olmaktadır. Sigorta poliçesi yapılırken zorunlu şart olarak gösterilen sprinkler sistemi 
veya hırsızlığı önlemek için alarm ve güvenlik sistemleri komşular için de faydası olacaktır. Ancak bu fayda komşuların poliçe yaptırmasında kolaylık sağlamayacaktır. Komşu bu güvenceye dayanarak belki sigorta poliçesi yaptırmaktan vazgeçebilecektir (Kunreuther vd., 2013: 193).

Tüm dünyada özel sağlık sigortalarında maliyet artışlarının önemli sebebi negatif dışsallıklardır. Örneğin beslenme alışkanlıklarında sağlıksız seçim yapan bireylerin sağlık sigorta sistemine, nispeten sağlıklı diğer bireylere göre, zarar verme ihtimali daha yüksektir (Bolin ve Cawley, 2007: 280). Aşırı şişman bireylerin hastalık riskine karşı poliçe yaptırma oranları da daha yüksektir. Bu kişilerin tercihi sağlık poliçeleri havuzundaki tüm bireylerin ödeyeceği primleri yükseltecektir (Bhattacharya ve Sood, 2006: 282).

Sigortanın temel işlevlerinden en önemli olanı "karşılıklı iyi niyet" prensibidir (Baştürk vd., 2017: 38). Sigortalı ve sigortacı poliçe düzenleme ve hasar aşamalarında birbirlerine karşılıklı olarak güvenirler. Poliçe aşamasında sigortalının beyanına göre hasar durumu ve teminat şekillenmektedir. Örneğin beslenme bozukluğu olan bir sigorta müşterisinin tam olmayan beyanına göre yetersiz risk analizi yapılacaktır. Hatalı ve kötü niyetli beyan sonucu hasar tazminatı alınması; sistemi olumsuz şekilde etkilemektedir (Heshmat, 2011: 69).

Bireyin özel sağlık sigortası olması durumunda sağlık kurumlarının tanı, tedavi ve ilaç aşamalarında diğer hastalara göre sağlık masraflarını daha fütursuzca kullandıkları bilinen bir gerçektir. Sağlık kurumunda bireyin sağlık sigortasını belirtmesi durumunda diğer hastalara göre giderleri arttırıcı işlemler yapılabilmektedir. Ayrıca özel sağlık sigortası olan bireyin doktor randevu ve ilaç taleplerinde daha rahat ve istekli davranma ihtimali de yüksektir (Starc ve Town, 2019: 3).

Bir sigorta poliçesinin satın alınma sürecinde, tarafların bilgi denkliğinin olmaması ters seçim sorununa sebep olmaktadır. Akerlof (1970: 489) bu örneği ikinci el otomobil pazarı ile izah etmiştir. Teorinin sigortaya adaptasyonunda; piyasada geniş ve dar teminatlı poliçeler bulunmaktadır. Müşteri tercih ettiği poliçenin nitelik ve kalitesi ile ilgili asimetrik bilgiye sahip olması durumunda, satın alma kararını tam olarak değerlendirememektedir. Sigortacı ise poliçe ile ilgili tüm bilgilere sahip olmasının rahatlığı ile daha gerçekçi bir prim belirlemektedir. Bu sonuç dar teminatlı poliçe sahiplerinin işine gelmektedir. Çünkü sigortalı hangi poliçenin kendisi için daha faydalı olduğunu ayırt edememektedir. Düşük primli poliçeler daha çok talep görmekte ve geniş teminatlı (yüksek primli) satışını sınırlamaktadır. Yani asimetrik bilgi sonucunda ters seçim yapılmaktadır.

Lüks araba kullanmak negatif dışsallıklar yaratır. Lüks otomobiller ile orta segment otomobillerin onarım maliyetleri arasında çarpıcı farklılıklar nedeniyle; tüm sürücüler için trafik mali sorumluluk sigorta maliyetlerini artırmaktadır. Araç kullanırken hangi tür bir araç ile trafik kazasına karışılacağı tahmin edilemez. Her ne kadar sürücü dikkatli olmaya çalışsa da herhangi bir sebepten meydana gelebilecek kazalara özellikle büyük şehirlerde lüks otomobillerin müdahil olma ihtimali yüksektir. Lüks otomobil sürücülerinin kullandığı araçların güvenlik özellikleri ve sigorta yaptırma gerekçesiyle de trafik kurallarına aykırı sürüş eğilimleri kaza riskini artırmaktadır (Park ve Han, 2017: 421). 


\section{Türk Sigorta Sisteminin Gelişimi}

Osmanlı Devleti'nde sigortacılığın 1870 "Pera Yangını" sonrası başladığı bilinmektedir. Bu dönemde sigortacılık sektörü tamamen yabancıların hakimiyetinde olup; tamamı Türk sermayeli bir sigorta şirketi mevut değildi. 1893 yılında kurulan ilk yerli sigorta şirketi; Tütün Rejisi, Duyu Umumiye ve Osmanlı Bankası ortaklığındaki "Osmanlı Umum Sigorta” olmuştur. Türkiye Cumhuriyeti'nin ilanıyla birlikte yerli sermayenin güçlenmesi hedeflenmiștir. 1925 y1lında kurulan Anadolu Anonim Türk Sigorta Şirketi Cumhuriyet döneminde tamamen yerli sermayeyle kurulan ilk sigorta şirketidir. Sigorta sektöründe 1980'li yıllarda başlayan liberalleşme hareketleri ile; sigorta şirketlerinin kurulmasında zorluklar kaldırılmış ve şirket sayıları hızla artmıştır. Bu durum aynı zamanda kamunun sektördeki etkisini artırmıştır. 2019 yılındaki toplam prim üretimi hayat dışında 58 milyar TL, Hayat branşında 11,3 milyar TL'dir. Kamu sigorta şirket sayısı; hayat dış1 3, hayat ise 3 toplam 6 şirkettir. Hayat dışı şirketlerin prim üretimindeki kamu payı: \%17,2, Hayat şirketlerin prim üretimindeki kamu payı: \%31,5 olup; toplamda bu pay, \%16'dır.

2007'de kabul edilen Sigortacılık Kanunu sonrası Türk sigorta sektörüne yönelen ilgi her geçen gün artmıştır. Kanun sonrası satın alma, birleşme ve yeniden kuruluş ile sektöre giren yabancı şirket sayısı artmıştır. Yabancı sermayeli şirket sayısı yaklaşık iki katı artarak 2019 yılı itibarı ile 38'e yükselmiştir.

Gelişmiş ülkelerle karşılaştırıldığında hala zayıf olan Türk sigorta sistemi 2000 yılından itibaren sigorta primini 2,64 Milyar ABD dolarından 2019 yılında yaklaşık 6 kat artmış ve 12 milyar ABD dolarına ulaşmıştır. Ancak gelişen finans sistemi içindeki payı ise sadece 2 katına yakın artış göstermiştir ve \%2,82 den \%4,70’e çıkabilmiştir. Kişi başına prim ise 40 ABD dolarından 2016 yılında 167 ABD dolarına kadar artış göstermiş ancak daha sonra dövizdeki aşırı yükselişle birlikte 2019 yılında 134 ABD dolarına düşmüştür.

Türkiye'de finansal sektörlerde en büyük pay bankacılık sektörüne ait olup; Tablo 1 'de görüldüğü üzere 2019 itibarı ile sigortacılığın payı \%4,7'dir. Türkiye'nin gelişme yolunda olan finansal sistemi içinde sigortacılığın payı hala hak ettiği yerde değildir. Türkiye'de de faaliyet gösteren Allianz'ın; Almanya DAX borsa endeksindeki payı \% 7,2 olmasına rağmen; sigorta sektörünün Borsa İstanbul'da payı \%2'den azdır (BİST, 2020; DAX, 2020). 
Tablo 1. Yıllar İtibari ile Prim Üretimi ve Finans Piyasası İçindeki Payı

\begin{tabular}{|c|c|c|c|c|c|}
\hline$\underset{\mathscr{E}}{\mathscr{E}}$ & Yll & $\begin{array}{c}\text { Toplam } \\
\text { Sigorta Prim } \\
\text { Üretimi } \\
\text { Milyar (\$) }\end{array}$ & $\begin{array}{l}\text { Prim/ } \\
\text { GSYH }\end{array}$ & $\begin{array}{l}\text { Kişi Başı } \\
\text { Prim (\$) }\end{array}$ & $\begin{array}{c}\text { Finans Sisteminde } \\
\text { Payı (\%) }\end{array}$ \\
\hline 1 & 2000 & 2,64 & 1,35 & 40 & 2,82 \\
\hline 2 & 2001 & 1,73 & 1,38 & 25 & 2,65 \\
\hline 3 & 2002 & 2,21 & 1,31 & 32 & 2,73 \\
\hline 4 & 2003 & 3,56 & 1,38 & 50 & 3,02 \\
\hline 5 & 2004 & 4,62 & 1,54 & 68 & 2,98 \\
\hline 6 & 2005 & 5,69 & 1,57 & 77 & 2,80 \\
\hline 7 & 2006 & 6,90 & 1,28 & 96 & 2,78 \\
\hline 8 & 2007 & 9,40 & 1,30 & 131 & 3,03 \\
\hline 9 & 2008 & 8,90 & 1,24 & 106 & 2,98 \\
\hline 10 & 2009 & 7,90 & 1,31 & 113 & 3,19 \\
\hline 11 & 2010 & 9,20 & 1,28 & 125 & 2,83 \\
\hline 12 & 2011 & 10,10 & 1,29 & 135 & 3,14 \\
\hline 13 & 2012 & 10,90 & 1,37 & 144 & 3,43 \\
\hline 14 & 2013 & 12,50 & 1,51 & 163 & 3,33 \\
\hline 15 & 2014 & 11,60 & 1,45 & 149 & 3,63 \\
\hline 16 & 2015 & 11,10 & 1,55 & 141 & 3,75 \\
\hline 17 & 2016 & 13,10 & 1,51 & 164 & 4,18 \\
\hline 18 & 2017 & 12,10 & 1,41 & 149 & 4,16 \\
\hline 19 & 2018 & 10,50 & 1,35 & 128 & 4,17 \\
\hline 20 & 2019 & 11,99 & 1,48 & 134 & 4,70 \\
\hline
\end{tabular}

Kaynak: TSB, 2020a

Türk sigorta sektörünün dünya içindeki payını gelişmiş ve gelişmekte olan ülkeler arasındaki yerini karşılaştırmalı olarak analiz etmek için 9 gelişmiş ülke ve 4 gelişmekte olan ülke verileri incelenmiştir. Tablo 2 incelendiğinde ABD prim üretiminde tüm ülkeler içinde açık ara önder durumda olduğu gözlenmektedir. 
Tablo 2. Ülke Karşılaştırması

\begin{tabular}{|c|c|c|c|c|c|c|c|c|c|}
\hline \multirow{2}{*}{ 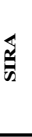 } & \multirow[b]{2}{*}{ ÜLKELER } & \multicolumn{4}{|c|}{2004} & \multicolumn{4}{|c|}{2017} \\
\hline & & $\begin{array}{c}\text { PRIMÜRETIMI } \\
\text { (MILYON \$) }\end{array}$ & $\begin{array}{c}\text { DÜNYA PRIM } \\
\text { ÜRETIMINDEKI } \\
\text { PAYI }(\%)\end{array}$ & KIŞİ BAŞSI PRIM(\$) & $\begin{array}{c}\text { PRIM/GSYH } \\
(\%)\end{array}$ & $\begin{array}{c}\text { PRIM ÜRETIMI } \\
\text { (MILYON S) }\end{array}$ & $\begin{array}{c}\text { DÜNYA PRIM } \\
\text { ÜRETIMINDEKI } \\
\text { PAYI }(\%)\end{array}$ & $\begin{array}{l}\text { Kişi̇ BASSI } \\
\text { PRIM(\$) }\end{array}$ & $\begin{array}{c}\text { PRIM/GSYH } \\
(\%)\end{array}$ \\
\hline 1 & ABD & 1.108 .110 & 34,02 & 3.590 & 9,44 & 1.399 .222 & 28,29 & 4.481 & 7,14 \\
\hline 2 & JAPONYA & 492.500 & 15,12 & 3.875 & 10,47 & 424.454 & 8,49 & 3.466 & 8,86 \\
\hline 3 & İNGILTERE & 288.594 & 8,86 & 4.484 & 12,50 & 319.992 & 6,48 & 4.503 & 10,61 \\
\hline 4 & ALMANYA & 191.036 & 5,56 & 2.285 & 6,87 & 227.174 & 4,65 & 2.908 & 6,03 \\
\hline 5 & FRANSA & 196.969 & 6,05 & 3.219 & 9,42 & 244.362 & 4,97 & 3.667 & 8,89 \\
\hline 6 & İTALYA & 129.421 & 3,97 & 2.213 & 7,59 & 159.271 & 3,28 & 2.852 & 8,34 \\
\hline 7 & ISPANYA & 56.002 & 1,72 & 1.358 & 5,38 & 70.486 & 1,43 & 1.588 & 5,20 \\
\hline 8 & KANADA & 70.300 & 2,16 & 2.206 & 7,09 & 121.181 & 2,46 & 3.457 & 7,48 \\
\hline 9 & GÜNEY KORE & 68.657 & 2,11 & 1.420 & 9,71 & 181.238 & 3,45 & 3.465 & 11,16 \\
\hline 10 & Çín & 52.171 & 1,60 & 40 & 3,15 & 541.446 & 11,07 & 406 & 4,22 \\
\hline 11 & TÜRKIYE & 4.619 & 0,14 & 64 & 1,54 & 12.054 & 0,20 & 127 & 1,33 \\
\hline 12 & MALEZYA & 6.453 & 0,20 & 256 & 5,33 & 15.408 & 0,32 & 518 & 4,77 \\
\hline 13 & RUSYA & 16.368 & 0,50 & 114 & 2,82 & 21.898 & 0,45 & 164 & 1,53 \\
\hline \multirow[t]{2}{*}{14} & ARJANTIN & 4.109 & 0,13 & 105 & 2,68 & 16.435 & 0,23 & 271 & 2,36 \\
\hline & DÜNYA & 3.257 .436 & 100 & 512 & 7,94 & 4.957 .507 & 100 & 682 & 6,09 \\
\hline
\end{tabular}

Kaynak: Swiss Re, 2005; 2018

ABD'nin dünya prim üretimindeki payı 2004-2017 arasında \%34,02'den \%28,29'a düşmüş olsa da hala birinciliği elde tutmaktadır. ABD'yi Japonya, İngiltere, Fransa ve Almanya gibi gelişmiş ekonomiler izlemektedir. Bu durum daha önce belirttiğimiz üzere sigorta sektörü ile ekonomik kalkınmanın birbirini desteklediğinin teyididir. Dünyanın en büyük 19. ekonomisi olan Türkiye'nin dünya prim üretimi içindeki payı ise $\% 0,20$ ile hakkedilmeyen seviyededir. Türkiye'deki prim oranı karşılaştırma yapılan gelişmekte olan ülkeler içinde de düşük olan ülke konumundadır.

Prim/GSYH oranında Güney Kore ABD'nin önüne geçmiş böylece Güney Kore GSYH'na oranla en çok prim üreten ülke olarak sigortaya verdiği önemi ortaya koymaktadır. Prim/GSYH oranı ise Türkiye'de 2004 yılında \%1.54 iken 2017 de \%1.33'e düşmüş. Bu veri İtalya, Kanada, Güney Kore, Çin dışındaki ülkelerde de zaman içinde düşmüştür. Sigorta sektörü diğer ülkelerde GSYH artışı oranında bir büyüme yakalayamamıştır. Türkiye karşılaştırdığımız 9 ülke içinde en düşük Prim/GSYH oranına sahiptir dolayısıyla Türkiye'deki sigortacılık sektörünün çok daha fazla gelişmesi için teşvike ihtiyacı vardır. Ayrıca kişi başına prim miktarında 127 ABD doları ile karşılaştırma yaptığımız ülkeler içinde en düşük miktara sahiptir. Çin kişi başına prim miktarını ekonomik büyümesine de bağlı olarak 2004'te 40 ABD dolarından 2017'de 406 ABD dolarına çıkarmıştır.

\section{Türk Sigorta Sisteminde Dışsallığa Etki Eden Kamu Politikaları}

Türkiye ekonomisinin büyüme hedeflerine ilişkin olarak sigorta sektörünün yaratacağı pozitif dışsallıktan sağlanacak faydayı ençoklaştırmak için özel sektörün desteklenmesi ve toplumsal faydanın arttırılması için 2000'li yıllardan itibaren düzenlemeler ve yeni uygulamalar ile kamu daha etkin rol oynamıştır.

Özellikle 2007 yılındaki 5684 sayılı Sigortacılık Kanunu sonrası hem yabancı şirket payı hem de mevzuatta gelişimler yaşanmış, kamu başta sigortalıların hakkını korumak ve sistemin etkin işlemesi amacı ile, bir dizi politikaları uygulamaya koymuştur (Resmi Gazete, 2007). Bu çalışmaların ağırlıklı olarak yeni kurumlar ve havuzlar olduğu görülmüştür. 
Güvence Hesabı Türkiye Sigorta Birliği yönetiminde 2007 yılında kurulmuştur. Güvence hesabı; zorunlu sigortalının belirlenememesi, geçerli sigortanın bulunmaması, gasp edilmiş veya çalınmış araçlarla yapılan kazalar ve sigorta şirketinin iflas etmesi durumunda; kazalarda zarar gören kişilerin uğrayacakları bedeni zararların karşılamaktadır. Kurum gelirini trafik sigorta primlerinden aktarılan yüzde üç pay ile sağlamaktadır. Bu durum da mağdur olan vatandaşlar için önemli destek sağlamaktadır.

2011 yılında yürürlüğü giren 6111 sayılı Kanun ile trafik sigorta primlerinden yüzde 10’luk pay SGK (Sosyal Güvenlik Kurumu) ya aktarılmıştır. SGK kazalar nedeniyle zarar gören kişilerin sağlık giderlerini karşılamaya başlamış ve trafik sigortalarındaki tedavi teminatı kaldırılmıştır. Trafik kazalarında yaralananlar için sosyal güvenlik şartı aranmadan kamu, üniversite ve özel sağlık kuruluşlarına gitme hakkı sağlanmıştır (Resmi Gazete, 2011a).

Trafik sigortalarında uygulanan serbest tarife sistemi, hasar prim oranı yüksek riskli sigortalılar için daha yüksek prim ödemesi esasına dayanmaktadır. Riskli sigortalıların primlerin yükselmesi ve ödenemez duruma gelmesi sonucunda; 27.10.2015 tarihinde uygulamaya giren Hazine Müsteşarlığı genelgesi ile poliçe primlerine azami fiyat gelmiştir (Hazine ve Maliye Bakanlığı , 2017). Sigorta havuzu işleyişi daha riskli olandan daha fazla prim alınması prensibine dayanmasına rağmen; uygulama ile riskli sigortalıdan alınması gereken prim havuzdaki diğer katılımcılara bölüştürülmeye başlanmıştır. Bu durum kaza yapmayan riski düşük vatandaşların daha fazla prim ödemesine ve trafik sigorta sisteminde negatif dişsallığa neden olmaktadir.

1999 Marmara depremi sonrası yaşanan büyük yıkım sonucu vatandaşların depremdeki zararları azaltmak amacı ile DASK (Doğal Afet Sigortaları Kurumu) 2000 yılında kurulmuştur. DASK poliçesi deprem hasarlarının ülkeye getireceği mali yükü ve vatandaşa yansıyabilecek muhtemel ek vergileri önleyebilmek amacı ile zorunlu hale getirilmiştir. Böylece devlet zorunlu deprem sigortası ile toplumda sosyal dayanışma ve sigorta bilincinin gelişmesine katkıda bulunmuştur. Bu pozitif dışsallığın sürekliliği için elektrik, su, doğalgaz abonelikleri ve bina satışlarında bu poliçeyi istenmektedir.

Sigorta şirketlerinin zorunlu trafik sigortası branşındaki zararlarının artmasına paralel, riskli sigortalılar için 11.07.2017 yılında bir havuz oluşturulmuştur. Bu kapsamdaki poliçelerin prim ve hasar paylaşımı için oluşturulan "Riskli Sigortalılar Havuzuna" yönetmelik gereği tüm sigorta şirketleri üye olmuştur (Resmî Gazete, 2017). Sigorta şirketleri bu tip riskleri havuza aktarma avantajı ile sigortalı seçimi kolaylaşmıştır. Uygulamanın riskli grupta olan sigortalıların daha kolay poliçe satın alması ve sigortalı oranın artması üzerinde pozitif bir dışsallık etkisi bulunmaktadır.

Tarım sigorta poliçelerinde standart sağlanması, prim ve hasarın tek merkezde kontrol edilmesi ve sigortanın yaygınlaştırılması amacı ile 2006 yılında Tarım Sigortaları Havuzu (Tarsim) kurulmuştur. Uygulamada de tarım üreticisi için sigorta prim desteği sağlamaktadır. Devlet doğal afet sonucu tarımda yaşanacak zararları kamu bütçesinden karşılamak yerine sigorta havuzuna devretmektedir. Çiftçilerin ödeyeceği primlere katkı sağlayarak sigortanın gelişimini desteklemektedir.

Türkiye'de 2003 yılında başlayan bireysel emeklilik sistemi 2013 yılında devletin katılımcılar için sağladığı katkı payı ile hızlanarak büyümeye başlamıştır. Devlet ilgili yıldaki brüt asgari ücretin \%25'ine kadar katılımcılar için destek sağlayarak fonların 
gelişmesini hızlandırmıştır. Kamunun teşvik ve desteği ile bireysel emeklilik fonları 2019 y1l sonu itibariyle yaklaşık 120 milyar TL'ye yükselmiştir (EGM, 2020).

2019 y1lından itibaren Türk sigorta sektöründe kamunun yaptığ 1 düzenlemeler ve kamu şirketleri ile etkisi daha fazla görülmeye başlanmıştır. 2019 yılında ilk kamu reasürans şirketi kurulmuştur. 2020 yılında ise 3 hayat dışı ve 3 hayat sigorta şirketleri birleşerek; Türkiye Sigorta ve Türkiye Hayat Emeklilik şirketleri kurulmuştur. Birleşerek yeniden kurulan her iki şirket de prim üretimi açısından ilk sıraya yükselmiştir.

Türkiye'de hayat dışı sigorta sektöründeki büyümenin ve sigortalılık oranının temel kaynağ1 özellikle zorunlu ve devlet destekli branşlardan gelmektedir. Ülkedeki sigortall1ık oranları zorunluk trafikte $\% 80$, zorunlu deprem $\% 50$, kasko $\% 30$, konut $\% 25$ civarındadır (TSB, 2020b). Hayat sigortalarının ise büyük bir payı kredi büyümesine bağlıdır.

Sigorta ürün ve hizmetleri konusunda toplumun bilinçlendirilmesi gerekmektedir. Toplumun sigorta farkındalığı konusunda bilinçlendirilmesi süreci, toplumu etkileyen baskın kültürel faktörlerin belirlenmesi ve bu kültürel faktörlerin sigorta talebi üzerindeki etkilerinin azaltılmasına yönelik olmalıdır (Soylu ve Kırkbeşoğlu, 2020: 1533).

\section{Sonuç ve Tartışma}

Türkiye ekonomisinin en büyük yapısal sorunlarından biri, tasarruf oranlarının düşüklüğü ve imalat sektörünün yüksek girdi bağımlılığından kaynaklanan cari açık problemidir. Ekonominin büyüme hızının arttığı dönemlerde büyümenin finansmanı için dışşal tasarruflara ihtiyaç artmakta ve cari açık beslenmektedir. Cari açık TL'nin değersizleşmesine ve kur geçişkenliği ile bir diğer önemli sorun olan enflasyonun yapışkanlığına ve kalıcı olmasına yol açarken ekonominin kırılganlığını arttırmaktadır. Ekonomik krizler arasındaki süre gittikçe kısalmakta ekonomik öngörülebilirliğin süresi kısaldıkça yatırımlar düşmekte ve işsizlik kalıcı hale gelmektedir. Enflasyon yaratmayacak ve işsizlik oranlarını düşürecek sürdürülebilir büyüme için, önemli şartlardan birisi de yatırımlar için gerekli fonların bulunabileceği derinleşmiş finansal piyasalardır. Güçlü finansal piyasalar için bankacılık sektörünün yanı sıra sigortacılık sektörünün de gelişmiş olması gerekir. Sigorta sektörü tasarruf oranlarını güven ortamını toplumsal dayanışmayı, uluslararası ticareti, yatırımlar için gereli olan fon arzını, istihdam kapasitesini arttırarak ekonomik büyüme ortamına önemli katkı sağlama imkanına sahiptir. Ayrıca Türkiye ekonomisinin gerek nüfus yapısının gerekse potansiyel büyüme kapasitesinin elverişli olması sigorta sektörüne doğrudan yabancı yatırımcılar için de cazibe merkezidir. 2004-2019 yıllarında Türk sigorta sektörüne 8,1 milyar ABD dolarlık yabancı sermaye girişi olmuştur

Sigorta sektörünün küresel milli gelire oran $1 \% 6$ civarındayken Türkiye bu oranın çok gerisindedir. $\mathrm{Bu}$ oranın yükseltilmesi ancak sigortalanma oranının artması ile mümkündür. Türkiye'de sigortalanma oranını artırma potansiyeli mevcuttur. $\mathrm{Bu}$ gelişimi etkileyen unsurların ekonomik, kültürel ve kamu kaynaklı olduğu görülmektedir. Ekonomik unsurlar büyüme, gelir düzeyi, kentleşme oranı ve çalışan nüfustur. Türkiye ile aynı gelir grubunda ve benzer sigorta prim üretimi olan Arjantin'de sigortacılığın milli gelire oranı yaklaşık iki kat fazladır. Bu oran İspanya'da Türkiye'nin üç katından fazladır. Türkiye'nin sigortanın milli gelire oranı gelişmekte olan ülkelere göre bile düşük kaldığından; uluslararası sigorta şirketlerine yatırım cazibe merkezi haline gelmiştir. 
Sigortacılık sektörü 2010-2019 dönemi yıllık ortalama \%20 büyümüştür. Sigorta sektörü 2020'den itibaren ekonomik büyüme artışı üzerinde gelecek 5 sene boyunca y1llık \%20 veya 10 sene boyunca yıllık $\% 10$ büyüme ile prim üretimini reel olarak iki katına çıkabilecektir. Böylece Türkiye Prim/GSYH oranını \%1,5 dan \%3 yükselterek, gelişmekte olan ülkeler ortalamasına ulaşacaktır. Aynı projeksiyon ile bir sonraki 510 yılda \%3'ten \%6'ya gelerek dünya ortalaması yakalanabilecektir. Gündemde olan tamamlayıcı emeklilik sisteminin oluşturulması; kamu ve düzenleyici otoriteler ile daha yakın çalışılması ile sektörün oynayacağı rolün etkinleştirilmesi sektörün toplam büyüklüğünün 2024 yılında 300-350 milyar TL seviyesine ulaşması hedeflenebilir (TSB, 2020b). Kamu kurumlarının etkin desteği ile Türkiye'nin sigortalanma oranı açısından pozitif ayrışan bir ülke olarak konumlanması mümkündür.

Ekonominin geneline yayılacak olan pozitif etkisi sebebiyle gelişmesi için desteğe ihtiyacı olan sigorta sektöründe devletin etkin rol oynaması serbest piyasa işleyişine uymamakla birlikte toplumsal yarar açısından önem kazanmaktadır. Kamu sigorta sistemindeki büyüme politikasının önemli ögesidir ve sigorta paydaşlarının birbirleri ile ilişkilerinde düzenleyici ve denetleyici rolü ile; sistem işleyişinde büyük bir etkisi bulunmaktadır. Türkiye'de 2019-2020 yılları arasında büyük bir kamu reasürans şirketi ve kamu sigorta şirketlerinin birleştirilmesi ile devletin sektördeki lider şirket rolü başlamıştır. Kamunun pazar yapıcı şirketlerinin sigortalanma oranının yükseltilmesinde önemli bir etkisi olacaktır. Yapılamayan sigorta türleri için havuzlar, zorunlu sigortalar için kontrol mekanizmaları, sigortalının sisteme güveninin sağlanması uygulamaları; kamu desteği ve denetimi ile yapılmalıdır.

Devletin düzenleyici ve denetleyici rolünün önemi özellikle pandemi krizi sürecinde anlaşılmış olup ekonomik sistemi yönlendirebilen ve politika üretim ile uygulamasında başarılı olan ülkelerin süreci daha iyi yönettiği gözlemlenmiştir. Türkiye ekonomisinde de özellikle sigorta sektörünün yarattığı dişsallıkların topluma yaygınlaştırılabilmesi için uzun dönemli politikalara ve kamu tarafından oluşturulacak düzenlemelere ihtiyaç vardır.

\section{Referanslar}

Acınan, H. (2005). Sigortanın temel prensipleri. İstanbul: Güneş Sigorta Yayınları.

Akerlof, G. A. (1970). The market for lemons: quality, uncertainty and the market mechanism, The Quarterly Jounal of Economics, 84(3), 488-500. DOI: $10.2307 / 1879431$.

Aksoy, N. (2017). İhracat kredi sigortası kavramı, hukukî niteliği ve benzer kurumlarla karşılaştırılması. Mehmet Akif Ersoy Üniversitesi İktisadi ve İdari Bilimler Fakültesi Dergisi, 4(1), 66-91. DOI: 10.30798/makuiibf.305956.

Alkin, E. (1992). İktisat. İstanbul: Filiz Kitabevi.

Arseven, H. (1987). Sigortanın tarihçesi ve geri kalmışlığımızın sebepleri. İstanbul Üniversitesi İktisat Fakültesi Mecmuası, 43(1-4), 415-431

Balta, S. G. İ. (1997). Türkiye'de sigorta sektörünün gelişimi, ekonomideki yeri ve önemi. (Yayınlanmamış yüksek lisans tezi). Hacettepe Üniversitesi Sosyal Bilimler Enstitüsü, Ankara.

Baştürk, F., Çakmak, D. ve Demirtaş, B. (2017). Sigortacılı̆̆a giriş. Ankara: Bankacılık Akademisi. 
Bhattacharya, J. ve Sood, N. (2006). Health insurance and the obesity externality. Advances in Health Economics and Health Services Research, DOI: 10.1016/S07312199(06)17011-9.

BİST (2020). Borsa İstanbul: İşlem gören şirketler. Erişim adresi https://www.borsaistanbul.com/tr/sayfa/73/islem-goren-sirketler

Bolin, K. ve Cawley, J. H. (2007). Advances in health economics and health services research volume 17: the economics of obesity. Oxford: JAI Press.

Bolin, K., Cawley, J. H., Grossman, M., Lindgren, B. (2007). The economics of obesity. Amsterdam: JAI Press Inc.

Çiftçi, H. (2004). Türk sigorta sektörünün sorunları: DEA analizi ile Türk sigorta şirketlerinin etkinlik düzeylerinin belirlenmesi. Çukurova Üniversitesi Sosyal Bilimler Enstitüsü Dergisi, 13(1), 121-149.

DAX (2020). Index composition report. DAX - German Indices, Deutsche Börse

Group. Erişim adresi https://www.daxindices.com/document/Resources/WeightingFiles/ Composition/ 2020/September/DAX_ICR.20200921.xls

EGM (2020). Emeklilik Gözetim Merkezi. Erişim adresi https://www.egm.org.tr/

Ehrlich, I. ve Becker, G. S. (1972). Market insurance, self-insurance and selfprotection. Journal of Political Economy, 80(4), 623-648. DOI: 10.1086/259916.

Fidan, M. M. (2011). Kobi kredi piyasasında asimetrik bilgi ve ahlaki tehlike: Laleli örneği. Maliye Finans Yazıları Dergisi, 90(1), 41-57.

Haller, M. (1975). Sicherheit durch versicherung, gedanken zur künftigen rolle der versicherung. Bern: Peter Lang.

Hartmann, P., Heider, H., Papaionnau, E. ve Lo Duca, M. (2007). The role of financial markets and innovation in productivity and growth in Europe: Occasional paper series No 72. Frankfurt: European Central Bank.

Heal, G. ve Kunreuther, H. (2005). You can only die once: Interdependent security in an uncertain world. Cheltenham: Edward Elgar Publishing.

Heshmat, S. (2011). Eating behavior and obesity: behavioral economics strategies for health professionals. New York: Springer Publishing Company.

Houtepen, R. ve Meulen, R. (2000). New types of solidarity in the European welfare state. Health Care Analysis, 8(4), 329-340.

Hofmann, A. (2009). Imperfect insurance markets: An economic analysis of externalities and consumer diversity, karlsruhe: Verlag Versicherungswirtschaft. Erişim adresi https://public.ebookcentral.proquest.com/choice/publicfullrecord.aspx?p=1204263

Hussels, S., Ward, D. ve Zurbruegg, R. (2005). Stimulating the demand for insurance. Risk Management and Insurance Review, 8(2), 257-278.

Karayolları motorlu araçlar zorunlu mali sorumluluk sigortası primlerine ilişkin genelge. (2017). Hazine ve Maliye Bakanlı̆̆ (2017/1).

KPMG (2020). Sigorta sektörüne bakış. Erişim adresi https://home.kpmg/tr/tr/ home/gorusler/2020/01 /sektorel-bakis-2020-sigortacilik.html 
Kunreuther, H. C., Pauly, M. V. ve McMorrow, S. (2013). Insurance and behavioral economics: Improving decisions in the most misunderstood industry. New York: Cambridge University Press. DOI: 10.1017/CBO9781139050319.

Mahul, O. ve Stutley, C. J. (2010). Government support to agricultural insurance: challenges and options for developing countries. Washington DC: World Bank Publications. Erişim adresi https://openknowledge.worldbank.org/handle/10986/2432

Özcan, H. (2020). Turkish insurance market. Turkey's economy from different perspectives after 1980. (Ed. E. Yllmaz ve N. Tekeli). Berlin: Peter Lang. DOI: $10.3726 / \mathrm{b} 16695$.

Park, S. C. ve Han, S. (2017). Externalities from driving luxury cars. Risk Management and Insurance Review, 20(3), 391-427. DOI: 10.1111/rmir.12085.

Riegel, R. ve Miller, J. S. (1966). Insurance principles and practices (5. Bask1). New Jersey: Prentice-Hall.

Seyfullahoğulları, Ç. A. ve Başoğlu, B. (2018). Türkiye'de özel sağlık sigortaları kapsamında prim üretimi ve gerçekleşen hasar analizi. İstanbul Sosyal Bilimler Dergisi, 22(1), 15-27.

Sigortacılık Kanunu (2007). T.C. Resmî Gazete (5684, 3 Haziran 2007).

Soylu, A. B. ve Kırbeşoğlu, E. (2020). Dini inançların sigorta talebi üzerindeki etkileri: Fenomenolojik bir araştırma. Üçüncü Sektör Sosyal Ekonomi Dergisi, 55(3), 1524-1539

Starc, A. ve Town, R. J. (2019). Externalities and benefit design in health insurance. The Review of Economic Studies, 1-32. DOI: 10.1093/restud/rdz052.

Sukhdev, P. (2012). Corporation 2020: Transforming business for tomorrow's world. Washington DC: Island Press. DOI: 10.1002/pfi.21441.

Swiss Re (2005). World insurance in 2004: Growing premiums and stronger balance sheets. Zurich: Swiss Re Institute.

Swiss Re (2018). World insurance in 2017: Solid, but mature life markets weigh on growth. Zurich: Swiss Re Institute.

Şengür, M. ve Taban, S. (2016). Gelir dağılımı-tasarruf ilişkisi: Türkiye'de hanehalkı gelir türünün tasarruflar üzerindeki etkisi. Anadolu Üniversitesi Sosyal Bilimler Dergisi, 16(1), 49-71.

Türk Ticaret Kanunu. (2011). T.C. Resmî Gazete (6102, 13 Ocak 2011).

TSB (2020a). Resmi istatistikler. Türkiye Sigorta, Reasürans ve Emeklilik Şirketleri Birliği. Erişim adresi https://www.tsb.org.tr/resmi-istatistikler.aspx ?pageID=909

TSB (2020). Türkiye Sigorta Birliği strateji raporu (2020-24). Erişim adresi https://www.tsb.org

Uralcan, G. Ş. (2004). Temel sigorta bilgileri ve sigorta sektörünün yapısal analizi. İstanbul: Beta Yayınevi.

Ünal, T. (1994). Sigorta sektörünün ekonomik işlevi ve fon yaratma kapasitesi. İstanbul: İstanbul Ticaret Odası Yayınları. 
Vickrey, W. (1968). Automobile accidents, tort law, externalities, and insurance: An economist's critique. Law and Contemporary Problems, 33(3), 464-487.

Ward, D. ve Zurbruegg, R. (2000). Does insurance promote economic growth? evidence from OECD Countries. The Journal of Risk and Insurance, 67(4), 489-506

Willett, A. H. (1901). The economic theory of risk and insurance, New York: The Columbia University Press, DOI: 10.9783/9781512808995.

Wu, C. ve Colwell, P. F. (1988). Moral hazard and moral imperative. The Journal of Risk and Insurance, 55(1), 101-117. DOI: 10.2307/253283

Yuca, H. (2012). Bankacılık sektöründe takipteki krediler-teminat ilişkisi (Yayınlanmamış doktora tezi). Kadir Has Üniversitesi Sosyal Bilimler Enstitüsü, İstanbul.

Yücememiş, B., Akpınar, Ö. ve Okay, G. (2011). Türk sigorta sektöründe yabancı payının sektöre olası etkileri: AB perspektifinde değerlendirme. Avrupa Araştırmaları Dergisi, 19(1), 53-75.

Zortuk, M. ve Ebeoğlugil, F. (2016). Seçilmiş geçiş ekonomilerinde insani kalkınma ve sigorta ilişkisi: Ampirik bir çalışma. Dumlupınar Üniversitesi Sosyal Bilimler Dergisi, Afro-Avrasya Özel Sayısı, 378-395. 